\title{
Erratum: PPARY activation but not PPARY haplodeficiency affects proangiogenic potential of endothelial cells and bone marrow-derived progenitors
}

\author{
Jerzy Kotlinowski ${ }^{1}$, Anna Grochot-Przeczek', Hevidar Taha' ${ }^{1}$, Magdalena Kozakowska', Bartosz Pilecki', \\ Klaudia Skrzypek', Jakub Zimoch ${ }^{1}$, Aleksandra Bartelik²,9 Rafal Derlacz ${ }^{3,4}$, Anton J G Horrevoets ${ }^{5}$, Attila Pap ${ }^{6}$, \\ Laszlo Nagy ${ }^{6,7,8}$, Jozef Dulak ${ }^{1}$ and Alicja Jozkowicz ${ }^{*}$
}

\section{Erratum}

After publication of this work [1], we noted that we inadvertently and accidentally failed to include one coauthor. The full list of authors has now been added and the Authors' contributions and Competing interests section modified accordingly.

\section{Competing interests}

The authors declare that they have no competing interests.
Received: 31 March 2015 Accepted: 31 March 2015 Published online: 29 May 2015

\section{Reference}

Kotlinowski J, Grochot-Przeczek A, Taha H, Kozakowska M, Pilecki B, Skrzypek K, et al. PPARy activation but not PPARy haplodeficiency affects proangiogenic potential of endothelial cells and bone marrow-derived progenitors. Cardiovasc Diabetol. 2014;13:150.

\begin{abstract}
Authors' contributions
JK participated in the design of the study and conducted experiments, analyzed data, performed the statistical analysis and wrote draft of the manuscript; AGP, HT, MK, BP, KS, JZ have been involved in performing experiments; $A B$ took care of animals; RD provided db/db mice; $A J G H$ analyzed microarray data; AP, LN provided PPARY mice; JD planned experiments and was involved in revising manuscript; AJ conceived of the study, designed and coordinated the study, wrote manuscript. All authors read and approved the final manuscript.
\end{abstract}

\section{Author details}

Department of Medical Biotechnology, Faculty of Biochemistry, Biophysics and Biotechnology, Jagiellonian University, Gronostajowa 7, 30-387 Krakow, Poland. ${ }^{2}$ Department of Biophysics, Faculty of Biochemistry, Biophysics and Biotechnology, Jagiellonian University, Krakow, Poland. ${ }^{3}$ R\&D Department, Adamed Ltd, Pienkow, Poland. ${ }^{4}$ Department of Metabolic Regulation, Institute of Biochemistry, Faculty of Biology, University of Warsaw, Warsaw, Poland. ${ }^{5}$ Department of Molecular Cell Biology and Immunology, VU University Medical Center, Amsterdam, The Netherlands. ${ }^{6}$ Department of Biochemistry and Molecular Biology, Faculty of Medicine, University of Debrecen, Debrecen, Hungary. "MTA-DE "Lendület" Immunogenomics Research Group, University of Debrecen, Debrecen, Hungary. ${ }^{8}$ Current address: Sanford-Burnham Medical Research Institute, Orlando, FL, USA. ${ }^{9}$ Current affiliation: Department of Molecular Neuropharmacology, Institute of Pharmacology Polish Academy of Science, Krakow, Poland.

\footnotetext{
* Correspondence: alicja.jozkowicz@uj.edu.pl

'Department of Medical Biotechnology, Faculty of Biochemistry, Biophysics and Biotechnology, Jagiellonian University, Gronostajowa 7, 30-387 Krakow, Poland

Full list of author information is available at the end of the article
}

\author{
Submit your next manuscript to BioMed Central \\ and take full advantage of: \\ - Convenient online submission \\ - Thorough peer review \\ - No space constraints or color figure charges \\ - Immediate publication on acceptance \\ - Inclusion in PubMed, CAS, Scopus and Google Scholar \\ - Research which is freely available for redistribution
}

Submit your manuscript at

www.biomedcentral.com/submit

\section{Ciomed Central}

(c) 2015 Kotlinowski et al.; licensee BioMed Central. This is an Open Access article distributed under the terms of the Creative Commons Attribution License (http://creativecommons.org/licenses/by/4.0) which permits unrestricted use, distribution, and reproduction in any medium, provided the original work is properly credited. The Creative Commons Public Domain Dedication waiver (http://creativecommons.org/publicdomain/zero/1.0/) applies to the data made available in this article, unless otherwise stated. 